\title{
防災投資の簡便な便益計測法に関する研究*
}

\section{The Simple Benefit Measurement Method of Natural Disaster Prevention Projects}

\section{高木 朗義**}

\author{
By Akiyoshi TAKAGI
}

\section{1.はじめに}

防災投資の社会的重要性は認知されているものの，現 有の経済資源すべてを投入できないという現実がある限 り，防災投資の便益を計測する等して，ある採択・優先 基準のもとに投資を行う必要がある．また防災投資の便 益を計測するためには，災害の特性である不確実性，地 域性を捉える必要があり，交通投資の場合と比べても複 雑な便益計測手法が必要な場合が多い，現在，わが国に おける防災投資の典型例である治水投資に対する費用便 益分析は, 1999年に改訂された治水経済調査マニュアル 1)に基づいて行われることとなったが，災害の特性の 1 つである地域性を捉えた土地利用変化（マニュアルでは 高度化便益）については計測手法が確立していないとし て，記載されていない状況にある。

不確実性下の便益定義については多くの研究事例があ る. $\mathrm{Graham}^{2)}$ 始め多くの研究が地域性を考慮しない 様々な不確実性下の便益定義を提案し, 多々納 3) はこれ らの特性を整理するとともに，新たな定義を提案してい る.これに対し上田 ${ }^{4}$, 高木他 ${ }^{5)}$ は地域性を考慮した便益 定義を提案している.

地域性を考慮した，いわゆる立地変化を捉えた便益計 測法も森杉他 ${ }^{6}$ ，上田 ${ }^{7}$ を始め多くの研究が行われている が，これらは不確実性を明示的に取り込んでいない。こ れに対し，高木他 ${ }^{8}$ は不確実性を明示的に取り入れた立 地均衡モデルを提案している. そこでは立地に関する均 衡計算を必要としており，現在数多く行われている防災 投資の費用便益分析に用いるのは経費的にも非常に厳し いと思われる．そこで本研究ではプロジェクト評価の実 務で簡単に使える，特に小規模なプロジェクトに有用な 簡便な便益計測手法を提案するものである.

本研究では提案する手法はショーカット法と呼ばれ， 煩雑な均衡計算を避け，市場から直接得られる情報で簡

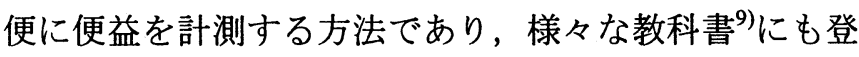
場するとともに，交通投資の便益評価に広く利用されて いる手法である. ショートカット法とは完全競争市場に おける間接効果はキャンセルアウトされてゼロとなり， 発生ベースの便益だけ計測すればよいとの考え方に基づ き,一般均衡理論の煩雑な計算作業を回避する方法とし て, 一般均衡理論のフレームの中で一市場, すなわち部

* キーワード : 整備効果計測法, 防災計画

**正員 博(工) 岐阜大学講師 工学部土木工学科

(岐阜市柳戸1-1 TEL:058-293-2445,FAX:058-230-1248)
分均衡的な計算により便益計測を行うとしたものであり, Kanemoto and Mera ${ }^{10)}$ や森杉・林山他 ${ }^{11)}$ など多くの研究者 によって提案されている. また，森杉・大野他 ${ }^{12}$ はその 拡張として環境改善, 寸なわち非市場財のショートカッ 卜法を提案し，立地変化を考慮した交通投資の便益計測 法としてのショートカット法も大野 ${ }^{13}$ が研究している. 本研究で提案するショートカット法は, 非市場財である こと及び立地変化，すなわち地域性を考慮しているとい う 2 点に加えて不確実性を追加したモデルあると位置付 けられる。

本研究で提案するショートカット法は，均衡計算を行 わずに立地変化による便益も捉えており，大規模でない 場合や多くの代替案に対する事前チェックを行う場合に は，作業が煩雑でないという点において利点がある．近 年の厳しい財政事情や合意形成問題を背景に今後益々費 用便益分析の重要性は高まると考えられ，小規模な事業 においても検討されるであろう。このように実際の多く の場面において適用できる手法を開発することは有益で あると思われる.

本研究では，まず各主体の行動を不確実性については 期待効用理論で捉え，地域性についてはランダム効用理 論で捉えた一般均衡理論の枠組みで社会経済モデルを構 築する. 次に，防災投資の便益を等価的偏差の概念を拡 張したNon-Contingent $\mathrm{EV}^{14)}$ で定義する. そしてその便益 定義の簡便な計測手法としてショートカット法を提案す る. 最後に数値シミュレーションを行い, 便益の推定精 度などを検討する。

\section{2. 社会経済モデル}

\section{(1) 社会経済モデルの仮定}

(1) 社会はいくつかの地域で構成されている. なお, 地域 内は均一空間であるものとする.

(2)社会は確率変動する環境状態で構成されている.

(3) 社会は同一の選好をもつ多数の世帯, 同じく同一の 選好をもつ多数の私企業（企業所有者），各地域每 に一括して土地を所有する地主, 政府の 4 部門と土 地市場, 労働市場, 合成財市場の 3 市場で構成され ているとする.

(4)世帯および私企業が土地サービスを需要するとき は，地主から土地を賃借する．すなわち，土地の使 用は賃貸借契約のみとし, 売買契約は考えない。

(5)立地均衡と土地取引は災害が起こるかもしれない 
将来を見越して現時点で行われると考え, ワルラス 的な多市場同時均衡に基づき, 各地域毎に土地サ一 ビスの取引量と地代が内生的に決定されるとする.

\section{（2）対象とする災害と発生確率}

災害の発生は，ある環境状態が発生する確率とその環 境状態における環境質によって決まるものとし, 本研究 では地域 $(j)$, 環境状態 $(i)$ 毎に異なる環境質 $H_{i}^{j}$ を考え, 環境状態の発生確率は地域毎に異なる $\phi_{i}^{j}\left(\sum_{i} \phi_{i}^{j}=1\right)$ で 与える. また, 環境質 $H_{i}^{j}$ は気象, 地形, 及び防災施 設水準など外生的に与えられる条件から成り立って おり，防災投資は環境質 $H_{i}^{j}$ と環境状態の発生確率 $\phi_{i}^{j}$ の 2 つを直接的に変化させるものと考える.

災害には地震災害, 風水害, 土砂災害, 火山噴火によ る災害など様々な種類があるが, 本研究では事前かつ地 域別に災害危険度, 寸なわち環境質 $H_{i}^{j}$ とその発生確率 $\phi_{i}^{j}$ がわかっている(物理量として客観的にわからなくて も各主体が主観的に判断できればよい）ことを前提条件 とするため, 想定する災害の種類や規模は, これを満足 する必要がある。 したがって, 稀少性, 巨大性, 集合性 をもつカタストロフな災害は想定おらず，どちらかとい うと小規模, 多頻度の災害を想定している. また, 土地 自体の消失や人命の損失などの不可逆な現象や資本形成 過程を明示的に取り扱っている訳ではないが，それらを 総合した地域の災害危険度を各主体が事前に想定できる 程度の災害を対象とする. 逆に言えば, 各主体が広い範 囲や規模が大きなものまで事前に災害危険度を判断でき れば，本モデルの適用範囲も広くなるであろうが，それ らは災害予測技術や情報公開などの程度によって決定さ れるため, 本モデルが想定できる規模, 範囲もそれに委 ねられることになると考えられる.

\section{(3) 世帯の行動モデル}

すべての世帯は任意の地域に居住するものとし， 2 段 階の最適化行動をとると仮定する. 第 1 段階は, 居住地 を仮に決めたときにとる消費活動の最適化行動であり, 地域, 環境状態毎の予算制約下で, 合成財需要量, 宅地 需要量及び余暇時間をコントロールして期待効用を最大 にするものとして, 次のように定式化する.

$$
\begin{gathered}
E^{j}\left(V_{i}^{j}\right)=\max _{z_{i}^{\prime}, a_{i}^{\prime}, T-l_{i}^{\prime}} E^{j}\left(U\left[z_{i}^{j}, a_{i}^{j}, T-l_{i}^{j}, H_{i}^{j}\right]\right) \\
\text { s.t. } \quad p_{i} z_{i}^{j}+r_{i}^{j} a_{i}^{j}=w_{i} l_{i}^{j}-g_{i}^{j}
\end{gathered}
$$

ここで, $E^{j}\left(V_{i}^{j}\right)$ : 期待効用水準, $V_{i}^{j}$ : 効用水準, $U[\cdot]$ : 効用関数, $E^{j}(U[\cdot])\left(=\sum_{i} \phi_{i}^{j} \cdot U[\cdot]\right)$ : 期待効用関数, $a_{i}^{j}$ : 宅地需要量, $z_{i}^{j}$ : 合成財消費量, $l_{i}^{j}$ : 労働時間, $T$ : 使 用可能時間, $p_{i}$ : 合成財価格, $r_{i}^{j}$ : 宅地地代, $w_{i}$ : 賃
金率, $g_{i}^{j}$ : 一括固定税.

式(1)を解くと，次式の期待間接効用関数を得る.

$$
E^{j}\left(V_{i}^{j}\right)=E^{j}\left(V\left[p_{i}, r_{i}^{j}, w_{i}, \Omega_{i}^{j}, H_{i}^{j}\right]\right)
$$

ここで, $V[\cdot]$ : 間接効用関数, $\Omega_{i}^{j}=w_{i} T-g_{i}^{j}$.

第 2 段階では, 地域での期待効用水準に従って居住地 を 1 つ選ぶと仮定する. 世帯が誤差項（ランダム変数） を持ち, それが独立かつGumbel分布に従うと仮定すると， 次式のLogitモデルを得る ${ }^{15)}$.

$$
\begin{gathered}
P^{j}=\frac{\exp \left\{\theta \cdot E^{j}\left(V_{i}^{j}\right)\right\}}{\sum_{j^{\prime}} \exp \left\{\theta \cdot E^{j^{\prime}}\left(V_{i}^{j^{\prime}}\right)\right\}} \\
S V=\frac{1}{\theta} \ln \left[\sum_{j} \exp \left\{\theta \cdot E^{j}\left(V_{i}^{j}\right)\right\}\right]
\end{gathered}
$$

ここで, $P^{j}$ : 立地選択確率, $\theta:$ Logitパラメータ,$S V$ : 包括的期待効用水準.

\section{（4）私企業（企業所有者）の行動モデル}

すべての私企業は任意の地域に立地するものとし，世 帯と同様な 2 段階の最適化行動をとると仮定する. 第 1 段階では，業務地を仮に決めたときにとる生産活動の最 適化行動を捉える. 不確実性下では利潤が定かでないと いう危険に直面しているため，このような危険に対する 企業の態度が決定的な役割を演じる ${ }^{16)}$.この点を勘案し, 企業の行動をわかり易くするため, 企業を所有し, 経営 をう人，すなわち企業所有者を想定してその行動を考え る. 具体的には, 利潤を変数とする効用関数を導入し, この効用の期待値の最大化が不確実性下における私企業 の目的であると考え，次のように定式化する ${ }^{16)}$.

$$
\begin{gathered}
E^{j}\left(V_{i}^{\prime j}\right)=\max _{A_{i}^{j}, Z_{i}^{\prime}, L_{i}^{j}} E^{j}\left(U^{\prime}\left[\pi_{i}^{j}\right]\right) \\
\text { s.t. } \pi_{i}^{j}=p_{i} Z_{i}^{j}-\left\{R_{i}^{j} A_{i}^{j}+w_{i} L_{i}^{j}+G_{i}^{j}\right\} \\
Z_{i}^{j}=Z\left[A_{i}^{j}, L_{i}^{j}, H_{i}^{j}\right]
\end{gathered}
$$

ここで, $E^{j}\left(V_{i}^{\prime j}\right)$ : 期待間接効用関数, $U^{\prime}[\cdot]$ : 効用関数, $\pi_{i}^{j}$ : 利潤, $A_{i}^{j}$ : 業務地需要量, $Z_{i}^{j}$ : 合成財生産量, $L_{i}^{j}$ : 労働力, $R_{i}^{j}$ : 業務地地代, $G_{i}^{j}$ :一括固定税, $Z[\cdot]$ : 生 産関数.

式(5)を解くと, 次式の期待間接効用関数を得る.

$$
\begin{gathered}
\pi_{i}^{j}=\pi\left[p_{i}, R_{i}^{j}, w_{i}, G_{i}^{j}, H_{i}^{j}\right] \\
E^{j}\left(V_{i}^{\prime j}\right)=E^{j}\left(V_{i}^{\prime j}\left[\pi_{i}^{j}\right]\right)
\end{gathered}
$$


ここで， $V^{\prime}[\cdot]$ : 間接効用関数.

第 2 段階では，私企業は地域の期待効用水準に従って 業務地を 1 つ選ぶと仮定する. 世帯の立地選択行動と同 様に考えると，次式のLogitモデルを得る.

$$
\begin{gathered}
P^{\prime j}=\frac{\exp \left\{\theta^{\prime} \cdot E^{j}\left(V_{i}^{\prime j}\right)\right\}}{\sum_{j^{\prime}} \exp \left\{\theta^{\prime} \cdot E^{j^{\prime}}\left(V_{i}^{j^{\prime}}\right)\right\}} \\
S V^{\prime}=\frac{1}{\theta^{\prime}} \ln \left[\sum_{j} \exp \left\{\theta^{\prime} \cdot E^{j}\left(V_{i}^{\prime j}\right)\right\}\right]
\end{gathered}
$$

ここで, $P^{\prime j}$ : 立地選択確率, $\theta^{\prime}:$ Logitパラメータ, $S V^{\prime}$ : 包括的期待効用水準.

\section{(5) 地主の行動モデル}

地主は, 地域, 環境状態毎の土地供給制約下で, 宅地 供給量と業務地供給量をコントロールして土地から得ら れる利潤を変数とした効用の期待值を最大化にするよう 行動すると仮定し，次のように定式化する.

$$
\begin{gathered}
E^{j}\left(V_{i}^{n j}\right)=\max _{k_{i}^{j}, K_{i}^{\prime}} \cdot E^{j}\left(U^{m}\left[\lambda_{i}^{j}\right]\right) \\
\text { s.t. } \quad \lambda_{i}^{j}=r_{i}^{j} k_{i}^{j}+R_{i}^{j} K_{i}^{j}-g_{i}^{\prime j} \\
k_{i}^{j}+K_{i}^{j} \leq \bar{K}_{i}^{j}\left[H_{i}^{j}\right]
\end{gathered}
$$

ここで, $E^{j}\left(V_{i}^{\prime \prime}\right)$ : 期待効用水準, $U^{n}[\cdot]$ : 効用関数, $\lambda_{i}^{j}$ : 利潤, $k_{i}^{j}$ : 宅地供給量, $K_{i}^{j}$ : 業務地供給量, $g_{i}^{\prime j}:$ 一 括固定税, $\bar{K}_{i}^{j}$ : 可住地面積.

式(9)を解くと, 次式の期待間接効用関数を得る.

$$
\begin{gathered}
\lambda_{i}^{j}=\lambda\left[\bar{K}_{i}^{j}, r_{i}^{j}, R_{i}^{j}, g_{i}^{j}, H_{i}^{j}\right] \\
E^{j}\left(V_{i}^{\prime \prime}\right)=E^{j}\left(V^{\prime \prime}\left[\lambda_{i}^{j}\right]\right)
\end{gathered}
$$

ここで, $V^{n}[\cdot]$ : 間接効用関数.

\section{(6) 政府の行動モデル}

政府は, 環境状態毎に各主体から税収を徵収して防災 投資を行うとし，収支バランスを次のように定式化する.

$$
\sum_{j} P^{j} N g_{i}^{j}+\sum_{j} P^{\prime j} M G_{i}^{j}+\sum_{j} g_{i}^{j}=\sum_{j} I_{i}^{j}
$$

ここで， $I_{i}^{j}$ : 防災投資額， $N$ : 総世帯数, $M$ : 総私企 業数.

災害による影響は，地域間での立地量の配分の変化では なく, 地域全体の立地量の変化であるため, 本モデルの ように地域全体の総世帯数, 総企業数を一定とすると,
過小評価になるという意見もあるが，地域全体を災害危 険度以外の要因で決まる立地選択範囲とすれば，地域全 体の総立地量が変化しないとしても過小評価にはならな いと考えられる。このような範囲を地域全体とすると大 きい場合もあるが，多くの場合は本モデルの適用範囲内 と考えられる.

\section{(7) 市場均衡条件}

本モデルにおける一般的な市場均衡条件は次のように 表される.

合成財 : $\sum_{j} P^{j} N \sum_{i} \phi_{i}^{j} z_{i}^{j}=\sum_{j} P^{j} M \sum_{i} \phi_{i}^{j} Z_{i}^{j}$

住宅地 : $P^{j} N \sum_{i} \phi_{i}^{j} a_{i}^{j}=\sum_{i} \phi_{i}^{j} k_{i}^{j}$

業務地 : $P^{\prime j} M \sum_{i} \phi_{i}^{j} A_{i}^{j}=\sum_{i} \phi_{i}^{j} K_{i}^{j}$

労㗢 : $\quad \sum_{j} P^{j} N \sum_{i} \phi_{i}^{j} l_{i}^{j}=\sum_{j} P^{\prime j} M \sum_{i} \phi_{i}^{j} L_{i}^{j}$

上記の社会経済モデルにおける未知数は $p_{i}, r_{i}^{j}, R_{i}^{j}$, $w_{i}$ で, その数は $(2 \times$ 地域数 +2$) \times$ 状態数である. これに 対し, 市場均衡条件式は $2 \times$ 地域数 +2 本しか存在しない ため, 一般的に上記の市場均衡条件式では唯一の均衡解 を有しない. したがって, 唯一の均衡解を有するのは, 各財について市場が環境状態毎に独立に成立しているか, 価格が期待值となる等, 環境状態にかかわらず変化しな いの何れかが成立している場合である.この 2 つのどち らが成立するかは災害の種類, 規模, 被災期間の継続す る長さ及び財の種類などに依存する. すべての財につい て前者が成立する場合は市場均衡条件式が $(2 \times$ 地域数 + 2) $\times$ 状態数となり, 後者が成立する場合は未知数が $2 \times$ 地 域数+2となるため, それぞれ唯一の均衡解を有すること となる. 土地は時間を越えて取り引きできないため, あ る時間断面における地域の環境状態の組合せは 1 通りで あり，前者が成立することとなる．また，合成財価格や 賃金率が環境状態毎に異なることを想定していることは, 暗に環境状態毎の需給バランスが異なる，すなわち，環 境状態毎に市場が独立して成立していることを想定して いると考えられる. これは比較的大規模な災害を想定し ていることとなるであろう。ささら実際には土地市場は 後者が成立している場合が多い，以下では，この条件の うち何れかが成立しているものの, それがどの条件であ るかは限定せず，展開を行うこととする．なお，住宅地 と業務地が競合する場合には, 土地市場が 1 つとなり, $r_{i}^{j}=R_{i}^{j}$ から解は唯一存在することとなる.

\section{（8）防災投資の効果}

政府は各主体からの税収をもとに防災投資を実施し， 環境質を $H_{i}^{A j}$ から $H_{i}^{B j}$ へ, 災害の発生確率を $\phi_{i}^{A j}$ から $\phi_{i}^{B j}$ 
へと変化させる．このとき，各主体の行動は変化し，市 場メカニズムを通して合成財価格 $p_{i}$, 地代 $r_{i}{ }^{j}, R_{i}^{j}$ 等が 変化する. この結果, 各主体の効用水準が $V_{i}^{A j}, V_{i}^{\prime A j}$, $V_{i}^{n A j}$ から $V_{i}^{B j}, V_{i}^{\prime B j} ， V_{i}^{n B j}$ 一と変化するとともに, 包括 的期待効用水準および期待効用水準が $S V^{A} ， S V^{\prime A}$, $E^{A}\left(V_{i}^{\prime A j}\right)$ から $S V^{B}, S V^{\prime B}, E^{B}\left(V_{i}^{\prime B j}\right)$ 一と変化する。こ のように防災投資の効果は, 社会経済フレームを通じて 世帯, 私企業, 地主の期待効用の増大として捉えること ができる.

\section{3. 防災投資の便益定義}

先に述べたように防災投資の便益定義には支払い形式 によってを設定によっていくつかの異なる定義が存在す る.このうち, 本研究では支払い形式が地域, 状態にか かわらず一定であるとしたNon-Contingent EVを防災投 資の便益定義とする ${ }^{14)}$.

防災投資を実施しない状態において，防災投資を実施 した場合の包括的期待効用水準 $S V^{B}$ を維持するという 条件の下に，防災投資を実施しない状態にとどまるため に必要であると個人が考える最小補償額であり, 次式を 構成する $N C E V$ で表される.

$S V^{B}=\frac{1}{\theta} \ln \left[\sum_{j} \exp \left\{\theta \cdot E^{A j}\left(V\left[p_{i}^{A}, r_{i}^{A j}, w_{i}^{A}, \Omega_{i}^{A j}+N E C V, H_{i}^{A j}\right]\right)\right\}\right]$

\section{4. ショートカット形の導出}

環境水準の変化は立地場所に依存しているため, そこ での土地需要の変化を伴うことは一般に認められる. そ のため, 事業が行われた地域での集計レベルの土地需要 （供給）関数を観察して，簡便的に便益を計測する方法 が考えられる.この簡便な便益計測手法がショートカッ ト法であり, 以下にその導出過程を示す.

\section{(1) Gorman型効用関数の適用}

各主体の間接効用関数を以下のようなGorman型で 定義する.

$$
\begin{aligned}
& V\left[p_{i}, r_{i}^{j}, w_{i}, \Omega_{i}^{j}, H_{i}^{j}\right] \\
= & \xi\left[p_{i}, r_{i}^{j}, w_{i}, H_{i}^{j}\right]+\eta\left[p_{i}, r_{i}^{j}, R_{i}^{j}, w_{i}, H_{i}^{j}\right] \Omega_{i}^{j} \\
V^{\prime}[ & {\left[\pi_{i}^{j}\right] } \\
= & \xi^{\prime}\left[p_{i}, R_{i}^{j}, w_{i}, G_{i}^{j}, H_{i}^{j}\right]+\eta\left[p_{i}, r_{i}^{j}, R_{i}^{j}, w_{i}, H_{i}^{j}\right] \pi_{i}^{j} \\
V^{\prime \prime} & {\left[\lambda_{i}^{j}\right] } \\
= & \xi^{\prime \prime}\left[\bar{K}_{i}^{j}, r_{i}^{j}, R_{i}^{j}, g_{i}^{j}, H_{i}^{j}\right]+\eta\left[p_{i}, r_{i}^{j}, R_{i}^{j}, w_{i}, H_{i}^{j}\right] \lambda_{i}^{j}
\end{aligned}
$$

$\eta[$.$] を主体，地域，状態によらず共通であると仮定する$ 必要がある.この仮定は強いが不確実性を考慮したショ 一トカット形を導出する上では避けられない. ただし， 最も簡単な場合として $\eta[]=$.1 とおけば, 所得, 利潤の変 化が効用の変化と同一であると解釈でき, 現実的である とも考えられる. しかし, Gorman型効用関数を導入する ことは，主体がリスク中立的な行動をとることを仮定す ることとなり，リスクプレミアムを持たない，あるいは リスク回避に対するオプション価值を 0 として, 期待所 得, 期待利潤そのもので行動することを意味する. した がって，本モデルでは，人命損失のような不可逆現象が 生じる災害や想定以上の大規模な災害など, リスク回避 行動を想定することを避けられない災害については, 適 用できないと言わざるを得ない。

これより社会的純便益 $S N B$ は次式のようになる.

$$
\begin{aligned}
S N B & =N \cdot N C E V+M \cdot N C E V^{\prime}+\sum_{j} E V^{n j} \\
& =N \cdot \frac{S V^{B}-S V^{A}}{E^{A j}\left(\eta_{i}^{A j}\right)}+M \cdot \frac{S V^{\prime B}-S V^{\prime A}}{E^{A j}\left(\eta_{i}^{A j}\right)} \\
& +\frac{\sum_{j}\left\{E^{B j}\left(V_{i}^{n B j}\right)-E^{A j}\left(V_{i}^{n}\right)\right\}}{E^{A j}\left(\eta_{i}^{A j}\right)}
\end{aligned}
$$

ここで, $E^{A j}\left(\eta_{i}^{A j}\right)$ : 地域 $j$ における withoutの $\eta_{i}^{j}$ の期待 值.

\section{(2) 㷌着形}

式(15)に各主体の行動モデル式を適用すると，社会的 純便益 $S N B$ は以下のように変形できる.

$$
\begin{gathered}
S N B=\frac{1}{E^{A j}\left(\eta_{i}^{A j}\right)} \oint_{A \rightarrow B}\left(\sum_{j} \sum_{i} P^{j} N V_{i}^{j} d \phi_{i}^{j}+\sum_{j} \sum_{i} P^{j} N \phi_{i}^{j} d V_{i}^{j}\right. \\
+\sum_{j} \sum_{i} P^{\prime j} M V_{i}^{\prime j} d \phi_{i}^{j}+\sum_{j} \sum_{i} P^{\prime j} M \phi_{i}^{j} d V_{i}^{\prime j} \\
\left.\quad+\sum_{j} \sum_{i} V_{i}^{n j} d \phi_{i}^{j}+\sum_{j} \sum_{i} \phi_{i}^{j} d V_{i}^{n j}\right) \\
=\frac{1}{E^{A j}\left(\eta_{i}^{A j}\right)} \oint_{A \rightarrow B}\left\{\sum_{j} \sum_{i}\left(P^{j} N V_{i}^{j}+P^{\prime j} M V_{i}^{\prime j}+V_{i}^{n j}\right) d \phi_{i}^{j}\right. \\
\left.\quad+\sum_{j} \sum_{i} \phi_{i}^{j}\left(P^{j} N d V_{i}^{j}+P^{\prime j} M d V_{i}^{\prime j}+d V_{i}^{n j}\right)\right\}
\end{gathered}
$$

ここで, $\oint$ は線積分を意味し,$A \rightarrow B$ は

$\left(p_{i}^{A}, r_{i}^{A j}, R_{i}^{A j}, w_{i}^{A}, \Omega_{i}^{A j}, \lambda_{i}^{A j}, \pi_{i}^{A j}, H_{i}^{A j}\right) \rightarrow$ $\left(p_{i}^{B}, r_{i}^{B j}, R_{i}^{B j}, w_{i}^{B}, \Omega_{i}^{B j}, \lambda_{i}^{B j}, \pi_{i}^{B j}, H_{i}^{B j}\right)$ を示している.

式(16)の $d V_{i}^{j}, d V_{i}^{\prime j}, d V_{i}^{m j}$ にロアの定理 ${ }^{17)}$ を適用し, $\Omega_{i}^{j}=w_{i} T-g_{i}^{j}$ を考慮して整理すると次のようになる. 


$$
\begin{aligned}
S N B= & \frac{1}{E^{A j}\left(\eta_{i}^{A j}\right)} \oint_{A \rightarrow B}\left\{\sum_{j} \sum_{i}\left(P^{j} N V_{i}^{j}+P^{\prime j} M V_{i}^{\prime j}+V_{i}^{n j}\right) d \phi_{i}^{j}\right. \\
& +\sum_{j} \sum_{i} \phi_{i}^{j} \eta_{i}^{j}\left(-P^{j} N z_{i}^{j} d p_{i}+P^{j} M Z_{i}^{j} d p_{i}\right. \\
& -P^{j} N a_{i}^{j} d r_{i}^{j}+k_{i}^{j} d r_{i}^{j} \\
& -P^{\prime j} M A_{i}^{j} d R_{i}^{j}+K_{i}^{j} d R_{i}^{j} \\
& +P^{j} N l_{i}^{j} d w_{i}-P^{\prime j} M L_{i}^{j} d w_{i} \\
& -P^{j} N d g_{i}^{j}+P^{\prime j} M d G_{i}^{j}-d g_{i}^{j} \\
& \left.\left.+P^{j} N \frac{\partial \Omega_{i}^{j}}{\partial H_{i}^{j}} d H_{i}^{j}+P^{\prime j} M \frac{\partial \pi_{i}^{j}}{\partial H_{i}^{j}} d H_{i}^{j}+\frac{\partial \lambda_{i}^{j}}{\partial H_{i}^{j}} d H_{i}^{j}\right)\right\}
\end{aligned}
$$

式(17)を防災投資の便益の帰着形と呼ぶことにする．な ぜなら, 式(17)における便益は世帯にとっての不確実性 変化 (災害発生確率の減少) の便益, 合成財価格低下の 便益, 地価上昇の不便益, 賃金率増大の便益, 所得増 大の便益, 環境質向上の便益, 私企業にとっての不確 実性変化 (災害発生確率の減少) の便益, 合成財価格低 下の不便益, 地価上昇の不便益, 賃金率増大の不便益, 税負担増大の不便益, 環境質向上の便益, および地主 にとっての不確実性変化 (災害発生確率の減少)の便 益, 地価上昇の便益, 税負担増大の不便益, 環境質向 上の便益の合計值で表現されているからである.

\section{（3）市場均衡条件の適用}

式(17)を整理すると次式が得られる.

$$
\begin{aligned}
& S N B=\frac{1}{E^{A j}\left(\eta_{i}^{A j}\right)} \oint_{A \rightarrow B}\left[\sum_{j} \sum_{i}\left(P^{j} N V_{i}^{j}+P^{\prime j} M V_{i}^{\prime j}+V_{i}^{n j}\right) d \phi_{i}^{j}\right. \\
& +\sum_{j} \sum_{i} \phi_{i}^{j} \eta_{i}^{j}\left\{\left(\frac{-P^{j} N z_{i}^{j}+P^{\prime j} M Z_{i}^{j}}{\mathbb{D}}\right) d p_{i}\right. \\
& +\left(\frac{-P^{j} N a_{i}^{j}+k_{i}^{j}}{(Q)}\right) d r_{i}^{j}+\left(\frac{-P^{j} M A_{i}^{j}+K_{i}^{j}}{\Theta}\right) d R_{i}^{j}
\end{aligned}
$$

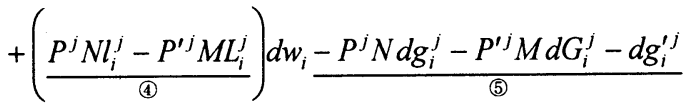

$$
\begin{aligned}
& \left.+\left(\frac{P^{j} N \frac{\partial \Omega_{i}^{j}}{\partial H_{i}^{j}}+P^{\prime j} M \frac{\partial \pi_{i}^{j}}{\partial H_{i}^{j}}+\frac{\partial \lambda_{i}^{j}}{\partial H_{i}^{j}}}{\odot)} d H_{i}^{j}\right\}\right]
\end{aligned}
$$

市場均衡条件式より，式(18)の (1)，(2)，(3)，(4)はゼ口 となる.また, 式(11)より(5)は $-d I_{i}^{j}$ となる.よって， $S N B$ は次式のように書き換えられる.

$$
\begin{aligned}
S N B= & \frac{1}{E^{A j}\left(\eta_{i}^{A j}\right)} \oint_{A \rightarrow B}\left(\sum_{j} \sum_{i}\left(P^{j} N V_{i}^{j}+P^{\prime j} M V_{i}^{j}+V_{i}^{\prime j}\right) d \phi_{i}^{j}\right. \\
& +\sum_{j} \sum_{i} \phi_{i}^{j} \eta_{i}^{j}\left(P^{j} N \frac{\partial \Omega_{i}^{j}}{\partial H_{i}^{j}} d H_{i}^{j}+P^{\prime j} M \frac{\partial \pi_{i}^{j}}{\partial H_{i}^{j}} d H_{i}^{j}+\frac{\partial \lambda_{i}^{j}}{\partial H_{i}^{j}} d H_{i}^{j}\right) \\
& \left.-\sum_{j} \sum_{i} \phi_{i}^{j} \eta_{i}^{j} d I_{i}^{j}\right\}
\end{aligned}
$$

式(19)より，防災投資実施による各財の価格変化とそれ に伴う需要供給量の変化 (波及効果) は, 各状態での消
費者余㮃の増分と生産者余剩の増分が一致するためにキ ヤンセルされることがわかる．また，式(19)の第 1 項は 災害発生頻度の減少による便益を, 第 2 項は各環境状態 の環境質の変化による便益を, 第 3 項は防災投資の投資 額を示している. なお, $\partial \Omega_{i}^{j} / \partial H_{i}^{j}, \partial \pi_{i}^{j} / \partial H_{i}^{j}, \partial \lambda_{i}^{j} / \partial H_{i}^{j}$ は各環境状態での世帯, 私企業, 地主の環境質 $H_{i}^{j}$ の限 界価值である.

特に, 土地価格が市場均衡で決定されている場合に は, その価格変化による消費者余㮃と生産者余剩の変 化分がキャンセルされるので, 土地価格変化そのもの を便益計算の対象から除外してもよいという事実を 式(19)は示している.

\section{(4) ショートカット形の誘導}

式(19)の第2項の\{ \}内は, 環境質の変化による便益で あり,このショートカット形は, 森杉·大野 ${ }^{13} に$ によって既 に提案されている.よって,ここでは第1項のみに着目し， 以下の手順に従ってショートカット形を誘導する.

(1)平常時と災害時の 2 つ状態のみを考え, サブスクリ プト0, 1 ( $0=$ =平常時, $1=$ 災害時) で表す. そして, 平 常時と災害時の発生確率の和が 1 であることから， $\phi_{0}^{j}=1-\phi_{1}^{j}$ より, $d \phi_{0}^{j}=-d \phi_{1}^{j}$ として整理すると次式の ようになる.

$$
\begin{aligned}
(\text { 第 } 1 \text { 項 })=\oint_{A \rightarrow B} \sum_{j} & \left\{P^{j} N\left(V_{0}^{j}-V_{1}^{j}\right)\right. \\
& \left.+P^{\prime j} M\left(V_{0}^{\prime j}-V_{1}^{\prime j}\right)+\left(V_{0}^{n j}-V_{1}^{\prime \prime}\right)\right\} d \phi_{0}^{j}
\end{aligned}
$$

(2) $V_{0}^{j}-V_{1}^{j}$ が地域 $j$ における平常時と災害時の効用差で あるため, \{ \}内を $1 \rightarrow 0$ (災害時 $\rightarrow$ 平常時) への線積 分で表し, $\Omega_{i}^{j}=w_{i} T-g_{i}^{j}$, 市場均衡条件を考慮して整 理した後, 平常時 0 のまわりでテーラー展開する.

(3)(2)て得られた式を式(20)に代入して整理した後, 防災 投資を行わない状態 $A$ のまわりでテーラー展開する.

(4)第2項のショートカット形と併せると, 社会的純便益 $S N B$ は, 次式のようになる.

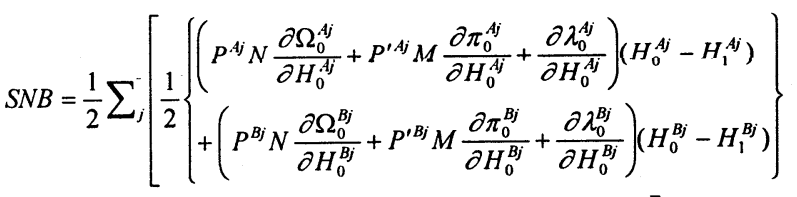

$$
\begin{aligned}
& \left.+\frac{1}{2}\left\{\begin{array}{l}
\left(P^{A j} N \frac{\partial \Omega_{1}^{A j}}{\partial H_{1}^{A j}}+P^{\prime A j} M \frac{\partial \pi_{1}^{A j}}{\partial H_{1}^{A j}}+\frac{\partial \lambda_{1}^{A j}}{\partial H_{1}^{A j}}\right)\left(H_{0}^{A j}-H_{1}^{A j}\right) \\
+\left(P^{B j} N \frac{\partial \Omega_{1}^{B j}}{\partial H_{1}^{B j}}+P^{\prime B j} M \frac{\partial \pi_{1}^{B j}}{\partial H_{1}^{B j}}+\frac{\partial \lambda_{1}^{B j}}{\partial H_{1}^{B j}}\right)\left(H_{0}^{B j}-H_{1}^{B j}\right)
\end{array}\right\} \phi_{0}^{B j}-\phi_{0}^{A j}\right) \\
& +\frac{1}{2} \sum_{j} \sum_{i} \phi_{i}^{j}\left(\begin{array}{l}
P^{A j} N \frac{\partial \Omega_{i}^{A j}}{\partial H_{i}^{A j}}+P^{\prime A j} M \frac{\partial \pi_{i}^{A j}}{\partial H_{i}^{A j}}+\frac{\partial \lambda_{i}^{A j}}{\partial H_{i}^{A j}} \\
+P^{B j} N \frac{\partial \Omega_{i}^{B j}}{\partial H_{i}^{B j}}+P^{B j} M \frac{\partial \pi_{i}^{B j}}{\partial H_{i}^{B j}}+\frac{\partial \lambda_{i}^{B j}}{\partial H_{i}^{B j}}
\end{array}\right)\left(H_{i}^{B j}-H_{i}^{A j}\right) \\
& \left.-\frac{1}{2} \sum_{j}\left\{\left(I_{0}^{A j}-I_{1}^{A j}\right)+\left(I_{0}^{B j}-I_{1}^{B j}\right)\right\} \phi_{0}^{B j}-\phi_{0}^{A j}\right)-\sum_{j} \sum_{i} \phi_{i}^{j}\left(I_{i}^{B j}-I_{i}^{A j}\right)
\end{aligned}
$$

式(21)をショートカット形と呼ぶ. この式では防災投資 
の社会的純便益 $S N B$ が，環境状態の発生確率 $\phi_{i}^{j}$ と環境 質 $H_{i}^{j}$ の変化のみで表されていることがわかる.

\section{5. ショートカット形の計測方法}

式(21)で示されたショートカット形の計測方法を以下 に示す. ただし, 世帯, 私企業, 地主とも同様に計測で きるので，以下では世帯についてのみ示す.

(1) 限界価値 $\times\left(H_{0}^{A j}-H_{1}^{A j}\right) \times\left(\phi_{0}^{B j}-\phi_{0}^{A j}\right)$ の計測方法

a) $P^{A j} N \partial \Omega_{0}^{A j} / \partial H_{0}^{A j} \times\left(H_{0}^{A j}-H_{1}^{A j}\right)$ の計測方法

防災投資を実施しなかった場合における災害時の環境 質 $H_{1}^{A j}$ の効用水準を維持するという条件の下で，世帯が $H_{0}^{A j} \rightarrow H_{1}^{A j}$ の変化を免れるために妥当と考える宅地の 地代を $r\left(H_{1}^{A j}\right)$ とする.これは次式を満たすような価格水 準である。

$$
V\left[p_{0}^{A}, r\left(H_{1}^{A j}\right), w_{0}^{A}, \Omega_{0}^{A j}, H_{0}^{A j}\right]=V\left[p_{0}^{A}, r_{0}^{A j}, w_{0}^{A}, \Omega_{0}^{A j}, H_{1}^{A j}\right]
$$

これを用いて変形すると，次式のようになる.

$$
\begin{aligned}
& P^{A j} N \frac{\partial \Omega_{0}^{A j}}{\partial H_{0}^{A j}}\left(H_{0}^{A j}-H_{1}^{A j}\right) \\
& =\int_{\left(H_{1}^{A j}\right)}^{r_{0}^{A j}} P^{A j} N \cdot a\left[p_{0}^{A}, r_{i}^{j}, w_{0}^{A}, \Omega_{0}^{A j}, H_{0}^{A j}\right] d r_{i}^{j}
\end{aligned}
$$

これは防災投資を実施しなかった場合の平常時の集計土 地需要関数における地代 $r_{0}^{A j}$ と $r\left(H_{1}^{A j}\right)$ の消費者余剩の差 分であり，図-1における $M D_{0}^{A}$ の面積を示す.

\section{b) $P^{A j} N \partial \Omega_{1}^{A j} / \partial H_{1}^{A j} \times\left(H_{0}^{A j}-H_{1}^{A j}\right)$ の計測方法}

防災投資を実施しなかった場合における平常時の環境 質 $H_{0}^{A j}$ の効用水準を維持するという条件の下で，世帯が $H_{0}^{A j} \rightarrow H_{1}^{A j}$ の変化を免れるために妥当と考える宅地の 地代を $r\left(H_{0}^{A j}\right)$ とする.これは次式を満たすような価格水 準である.

$$
V\left[p_{1}^{A}, r\left(H_{0}^{A j}\right), w_{1}^{A}, \Omega_{1}^{A j}, H_{1}^{A j}\right]=V\left[p_{1}^{A}, r_{1}^{A j}, w_{1}^{A}, \Omega_{1}^{A j}, H_{0}^{A j}\right]
$$

これを用いて変形すると，次式のようになる.

$$
\begin{aligned}
& P^{A j} N \frac{\partial \Omega_{1}^{A j}}{\partial H_{1}^{A j}}\left(H_{0}^{A j}-H_{1}^{A j}\right) \\
& =\int_{1}^{\left(H_{0}^{A j}\right)} P^{A j} N \cdot a\left[p_{1}^{A}, r_{i}^{j}, w_{1}^{A}, \Omega_{1}^{A j}, H_{1}^{A j}\right] d r_{i}^{j}
\end{aligned}
$$

これは防災投資を実施しなかった場合の災害時の集計土 地需要関数における地代 $r_{1}^{A j}$ と $r\left(H_{0}^{A j}\right)$ の消費者余剩の差
分であり, 図-1における $M D_{1}^{A}$ の面積を示す.

式(22b),(23b)は，防災投資を実施しなかった場合にお ける平常時から災害時への環境質の変化に等価な地代の 変化を発見することによって，災害の発生により悪化す る住環境の質の限界価値を集計土地需要関数のシフトを 考慮した消費者余剩で計測できることを意味している.

したがって, 式(21)におけるこの項は, 図-1の 2 つの斜 線部分の平均面積で表される消費者余剩に防災投資によ る環境状態の発生確率の変化分を乗じ, 地域毎に合計す ることで計測できる.

(2) 限界価値 $\times\left(H_{0}^{B j}-H_{1}^{B j}\right) \times\left(\phi_{0}^{B j}-\phi_{0}^{A j}\right)$ の計測方法

a) $P^{B j} N \partial \Omega_{0}^{B j} / \partial H_{0}^{B j} \times\left(H_{0}^{B j}-H_{1}^{B j}\right)$ の計測方法

防災投資を実施した場合における災害時の環境質 $H_{1}^{B j}$ の効用水準を維持するという条件の下で，世帯が $H_{0}^{B j} \rightarrow H_{1}^{B j}$ の変化を免れるために妥当と考える宅地の 地代を $r\left(H_{1}^{B j}\right)$ とする.すなわち，次式を満たすような 価格水準である。

$$
V\left[p_{0}^{B}, r\left(H_{1}^{B j}\right), w_{0}^{B}, \Omega_{0}^{B j}, H_{0}^{B j}\right]=V\left[p_{0}^{B}, r_{0}^{B j}, w_{0}^{B}, \Omega_{0}^{B j}, H_{1}^{B j}\right]
$$

これを用いて変形すると，次式のようになる．

$$
\begin{aligned}
& P^{B j} N \frac{\partial \Omega_{0}^{B j}}{\partial H_{0}^{B j}}\left(H_{1}^{B j}-H_{0}^{B j}\right) \\
& =\int_{\left(H_{1}^{B_{j}}\right)}^{B_{j} j} P^{B j} N \cdot a\left[p_{0}^{B}, r_{i}^{j}, w_{0}^{B}, \Omega_{0}^{B j}, H_{0}^{B j}\right] d r_{i}{ }^{j}
\end{aligned}
$$

これは防災投資を実施した場合の平常時の集計土地 需要関数における地代 $r_{1}^{B j}$ と $r_{i}^{j}\left(H_{1}^{B j}\right)$ の消費者余剩の 差分であり，図-2における $M D_{0}^{B}$ の面積を示す.

\section{b) $P^{B j} N \partial \Omega_{1}^{B j} / \partial H_{1}^{B j} \times\left(H_{0}^{B j}-H_{1}^{B j}\right)$ の計測方法}

防災投資を実施した場合における平常時の環境質 $H_{0}^{B j}$ の効用水準を維持するという条件の下で，世帯が $H_{0}^{B j} \rightarrow H_{1}^{B j}$ の変化を諦めるために妥当と考える宅地の 地代を $r_{i}^{j}\left(H_{0}^{B j}\right)$ とする.すなわち, 次式を満たすよう な価格水準である.

$$
V\left[p_{1}^{B}, r_{i}^{j}\left(H_{0}^{B j}\right), w_{1}^{B}, \Omega_{1}^{B j}, H_{1}^{B j}\right]=V\left[p_{1}^{B}, r_{1}^{B j}, w_{1}^{B}, \Omega_{1}^{B j}, H_{0}^{B j}\right]
$$

これを用いて変形すると，次式のようになる．

$$
\begin{aligned}
& P^{B j} N \frac{\partial \Omega_{1}^{B j}}{\partial H_{1}^{B j}}\left(H_{0}^{B j}-H_{1}^{B j}\right) \\
& =\int_{1}^{\left(H_{0}^{B j}\right)} P^{B j} N \cdot a\left[p_{1}^{B}, r_{i}^{j}, w_{1}^{B}, \Omega_{1}^{B j}, H_{1}^{B j}\right] d r_{i}^{j}
\end{aligned}
$$




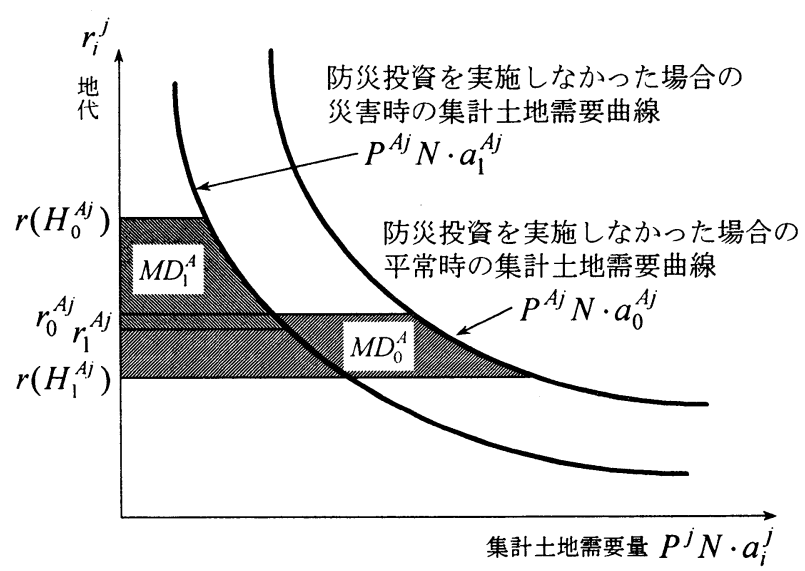

図-1 $P^{A j} N \partial \Omega_{i}^{A j} / \partial H_{i}^{A j} \times\left(H_{0}^{A j}-H_{1}^{A j}\right)$ の計測方法

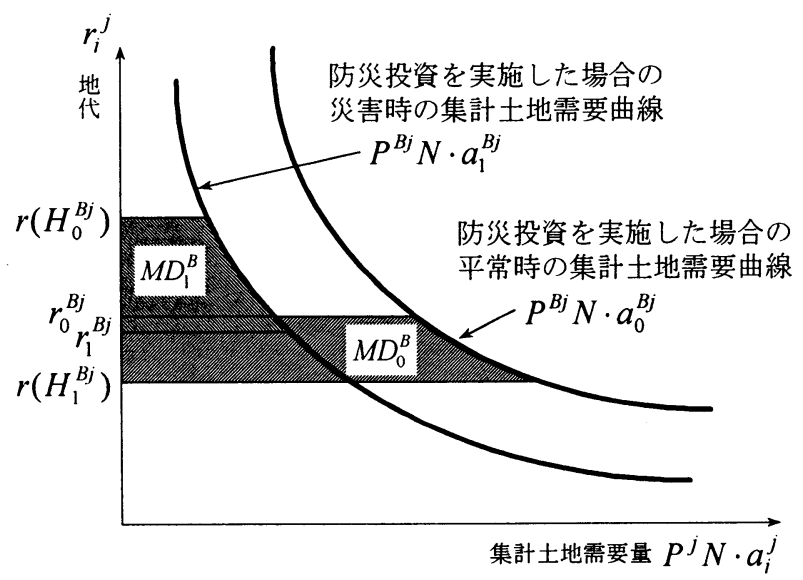

図-2 $P^{B j} N \partial \Omega_{i}^{B j} / \partial H_{i}^{B j} \times\left(H_{0}^{B j}-H_{1}^{B j}\right)$ の計測方法

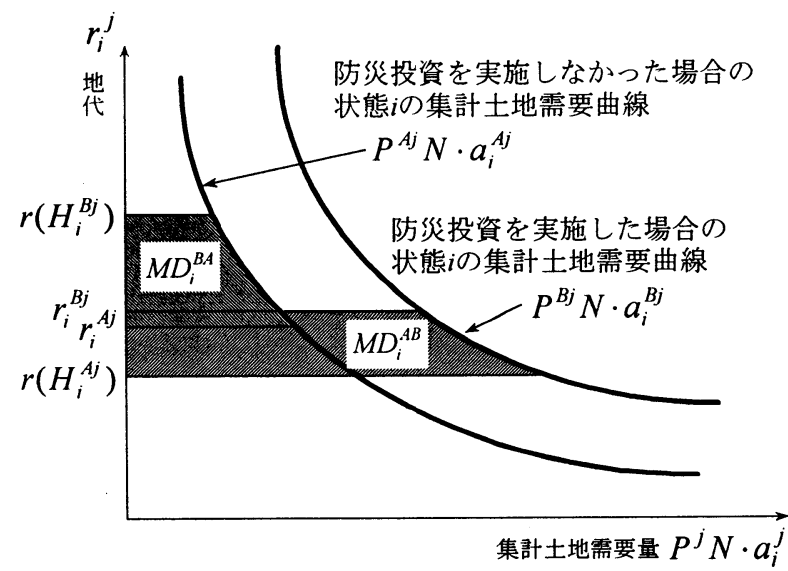

図-3 $P^{A j} N \partial \Omega_{i}^{A j} / \partial H_{i}^{A j} \times\left(H_{i}^{B j}-H_{i}^{A j}\right)$ と $P^{B j} N \partial \Omega_{i}^{B j} / \partial H_{i}^{B j} \times\left(H_{i}^{B j}-H_{i}^{A j}\right)$ の計測方法

これは防災投資を実施した場合の災害時の集計土地 需要関数における地代 $r_{1}^{B j}$ と $r\left(H_{0}^{B j}\right)$ の消費者余剩の差 分であり，図-2における $M D_{1}^{B}$ の面積を示す.

式(24b),(25b)は，防災投資を実施した場合での平常 時から災害時への環境状態の変化による環境質の変
化に等価な地代の変化を発見することによって，各環 境状態の環境質 $H_{i}^{B j}$ の限界価値, すなわち災害が発生 したことにより悪化する住環境の質の限界価値を集 計土地需要関数のシフトを考慮した消費者余剩で計 測できることを意味している．したがって，式(21)に おけるこの項は, 図-2の 2 つの斜線部分の平均面積で 表される消費者余剩に防災投資による環境状態の発 生確率の変化分 (平常時または災害時の発生確率の変 化分）を乗じ，地域毎に合計することで計測できる.

(3) 限界価値 $\times\left(H_{i}^{B j}-H_{i}^{A j}\right)$ の計測方法

a) $P^{A j} N \partial \Omega_{i}^{A j} / \partial H_{i}^{A j} \times\left(H_{i}^{B j}-H_{i}^{A j}\right)$ の計測方法

環境状態毎の防災投資を実施した場合の環境質 $H_{i}^{B j}$ の効用水準を維持するという条件の下で, 世帯が $H_{i}^{A j} \rightarrow H_{i}^{B j}$ の変化を諦めるために妥当と考える宅地の 地代を $r\left(H_{i}^{B j}\right)$ とする. すなわち，次式を満たすような 価格水準である.

$$
V\left[p_{i}^{A}, r_{i}^{j}\left(H_{i}^{B j}\right), w_{i}^{A}, \Omega_{i}^{A j}, H_{i}^{A j}\right]=V\left[p_{i}^{A}, r_{i}^{A j}, w_{i}^{A}, \Omega_{i}^{A j}, H_{i}^{B j}\right]
$$

これを用いて変形すると，次式のようになる．

$$
\begin{aligned}
& P^{A j} N \frac{\partial \Omega_{i}^{A j}}{\partial H_{i}^{A j}}\left(H_{i}^{B j}-H_{i}^{A j}\right) \\
& =\int_{i^{\prime \prime}}^{\left(H^{B j}\right)} P^{A j} N \cdot a\left[p_{i}^{A}, r_{i}^{j}, w_{i}^{A}, \Omega_{i}^{A j}, H_{i}^{A j}\right] d r_{i}^{j}
\end{aligned}
$$

これは防災投資を実施しなかった場合の環境状態毎 の集計土地需要関数における地代 $r_{i}^{A j}$ と $r\left(H_{i}^{B j}\right)$ の消費 者余劋の差分であり, 図-3の $M D_{i}^{A B}$ の面積を示す.

\section{b) $P^{B j} N \partial \Omega_{i}^{B j} j \partial H_{i}^{B j} \times\left(H_{i}^{B j}-H_{i}^{A j}\right)$ の計測方法}

環境状態毎の防災投資を実施しなかった場合の環 境質 $H_{i}^{A j}$ の効用水準を維持するという条件の下で，世 帯が $H_{i}^{A j} \rightarrow H_{i}^{B j}$ の変化を獲得するために妥当と考える 宅地の地代を $r\left(H_{i}^{A j}\right)$ とする.すなわち, 次式を満たす ような価格水準である.

$$
V\left[p_{i}^{B}, r\left(H_{i}^{A j}\right), w_{i}^{B}, \Omega_{i}^{B j}, H_{i}^{B j}\right]=V\left[p_{i}^{B}, r_{i}^{B j}, w_{i}^{B}, \Omega_{i}^{B j}, H_{i}^{A j}\right]
$$

これを用いて変形すると，次式のようになる．

$$
\begin{aligned}
& P^{B j} N \frac{\partial \Omega_{i}^{B j}}{\partial H_{i}^{B j}}\left(H_{i}^{B j}-H_{i}^{A j}\right) \\
& =\int_{\left(H_{i}^{A j}\right)}^{B_{j}^{B j}} P^{B j} N \cdot a\left[p_{i}^{B}, r_{i}^{j}, w_{i}^{B}, \Omega_{i}^{B j}, H_{i}^{B j}\right] d r_{i}^{j}
\end{aligned}
$$

これは防災投資を実施した場合の環境状態毎の集計 
土地需要関数における地代 $r_{i}^{A j}$ と $r\left(H_{i}^{A j}\right)$ の消費者余剩 の差分であり, 図-3の $M D_{i}^{B A}$ の面積を示す.

式(26b),(27b)は，防災投資の実施による環境質の変 化に等価な地代の変化を発見することによって, 各環 境状態の環境質 $H_{i}^{j}$ の限界価値, 寸なわち防災投資を 実施することにより改善される住環境の質の限界価 值を集計土地需要関数のシフトを考慮した消費者余 剩で計測できることを意味している．したがって，式 (21)におけるこの項は, 図-3の 2 つの斜線部分の平均 面積で表される消費者余楼の期待値を地域毎に合計 することで計測できる.

\section{（4）投資額に関連する項目の計測方法}

a) $1 / 2 \sum_{j}\left\{\left(I_{0}^{A j}-I_{1}^{A j}\right)+\left(I_{0}^{B j}-I_{1}^{B j}\right)\right\} \times\left(H_{0}^{B j}-H_{0}^{A j}\right)$ の計測方法

防災投資を実施しなかった場合の平常時と災害時 の防災投資額の差と防災投資を実施した場合の平常 時と災害時の防災投資額の差との平均に，防災投資に よる環境状態の発生確率の変化分 (平常時または災害 時の発生確率の変化分) を乗じ, 地域毎に合計するこ とで計測できる.

\section{b) $\sum_{j} \sum_{i} \phi_{i}^{j}\left(I_{i}^{B j}-I_{i}^{A j}\right)$ の計測方法}

防災投資を実施した場合の各環境状態における防 災投資額と防災投資を実施しなかった場合の各環境 状態における防災投資額の差の期待值で計測できる.

\section{(5) ショートカット形の計測方法のまとめ}

以上の計測方法を整理すると次のようになる.

$$
\begin{aligned}
S N B & =\frac{1}{4} \sum_{j} \sum_{i}\left(M D_{i}^{A}+M D_{i}^{B}\right)\left(\phi_{0}^{B j}-\phi_{0}^{A j}\right) \\
& +\frac{1}{2} \sum_{j} \sum_{i} \phi_{i}^{A j}\left(M D_{i}^{A B}+M D_{i}^{B A}\right)-(\text { 防災投資額 })
\end{aligned}
$$

式(28)によると，防災投資による社会的純便益は，

(1)防災投資を実施しなかった場合における災害時と 平常時の消費者余剩の差に, 災害の発生確率の変化 を乗じて，地域毎に合計する。

(2)防災投資を実施した場合における災害時と平常時 の消費者余剩の差に, 災害の発生確率の変化を乗じ て，地域毎に合計する.

(3) 災害時と平常時のそれぞれについて, 防災投資を実 施した場合としなかった場合における消費者余剩 の差を求め，その期待值を地域毎に合計する.

の合計から

(4) 防災投資額分

を引いたものとして計測できることを示している.

なお，(1)〜 (3)を計測するためには，防災投資の有無
別, 環境状態別に需要曲線を推定する必要があり，そ のためのデータが必要となる. しかし, すべてのデー 夕を対象地域において事前に入手することは困難で あり，実際には他地域で観測されたデータ等をもとに， 推定せざるを得ない場合が多いと思われる.

\section{6. 数值シミュレーション}

本研究で導出したショートカット法を用いて, S川に おける総合治水対策事業による便益計測のシミュレーシ ヨンを行った. S川流域はG市郊外に位置し, 近年の急激 な市街化により流出の集中化と增大が著しく，相対的に 河道流下能力が低下している. 現在S川では総合治水対 策事業が進められている. 河道と想定氾濫区域の模式図 を図-4に示す。

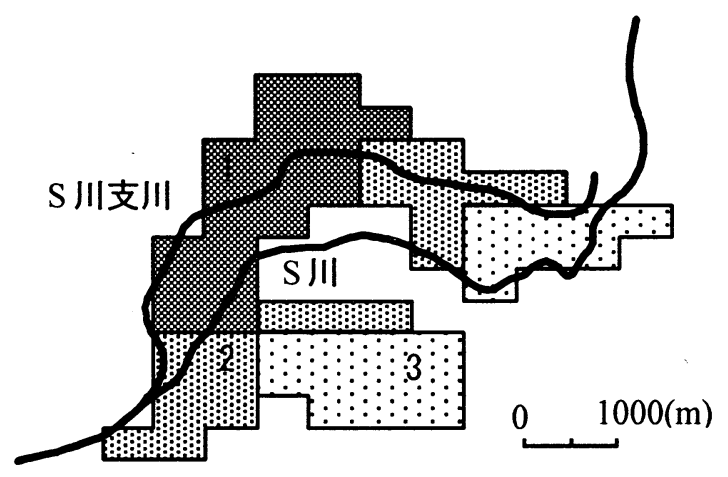

図-4 対象河川と想定汇濫区域の模式図

便益計測に当たっては，まず想定氾監区域を 3 ゾーン に区分し，ショートカット法を適用するために必要なデ 一タとして各ゾーンにおける市街化面積, 平均地代を整 理した. 次に別途行った汇濫計算結果から，想定氾濫区 域内の何れのメッシュでも床上浸水が発生しない場合を 平常時, それ以外を洪水時と想定して, 平常時と洪水時 におけるゾーン毎の期待平均浸水深（メッシュ数で加重 平均值）を求めた. その結果は表-1の上段部分に示すと おりである. なお，withの地代が高いにもかかわらず集 計土地需要量が大きくなっているのは, withoutに比べて 治水安全度が向上していることにより, 需要関数がシフ トしているためである（例えば，図-3参照）。

ショートカット法を適用するためには, 様々なケース における地代を求める必要がある. 本来ならば流域内及 び周辺地域における地代データと集計土地需要量（市街 化面積）や浸水深との関係を調べたり，もしくは住民に アンケートを行って, 各ケースの地代を求めるところで あるが，ここでは高木他 ${ }^{8)}$ で行っているシミュレーショ ンの効用関数を流用して各ケースの投資を諦める值を求 めている.このことは間接的ではあるが立地均衡モデル を利用していることであり, ショートカット法の利点で ある簡便性を実証分析において検討し切れないと言う反 論もあろうが，ここではショートカット法の近似精度の 
表-1 数値シミュレーションの条件と結果

\begin{tabular}{|c|c|c|c|c|c|c|c|c|c|}
\hline & & 顶日 & & 単位 & 記 문 & & ゾーン & & 計 \\
\hline & & 熕日 & & 早位 & 呪 万 & 1 & 2 & 3 & 耐 \\
\hline & & 状態の生 & 平常時 & - & $\phi_{0}{ }^{A j}$ & 0.667 & 0.667 & 0.667 & \\
\hline & without & 起確率 & 洪水時 & - & $\phi_{1}^{A j}$ & 0.333 & 0.333 & 0.333 & \\
\hline & Witnout & 年平均期 & 平常時 & $\mathrm{m}$ & $H_{0}{ }^{A j}$ & 0.041 & 0.071 & 0.045 & \\
\hline 績 & & 待浸水深 & 洪 水時 & $\mathrm{m}$ & $H_{1}{ }^{A j}$ & 0.128 & 0.156 & 0.111 & \\
\hline 值 & & 状 態の生 & 平常時 & - & $\phi_{0}^{B j}$ & 0.800 & 0.800 & 0.800 & \\
\hline 及 & with & 起確率 & 洪水時 & - & $\phi_{1}^{B j}$ & 0.200 & 0.200 & 0.200 & \\
\hline び & With & 年平均期 & 平常時 & $\mathrm{m}$ & $H_{0}^{B j}$ & 0.008 & 0.005 & 0.008 & \\
\hline 推 & & 待浸水深 & 洪水時 & $\mathrm{m}$ & $H_{1}^{B j}$ & 0.082 & 0.086 & 0.082 & \\
\hline 訫 & 隻計十 & 地電西昌 & without & $\mathrm{m}^{2}$ & $P N a_{i}{ }^{A j}$ & 919,358 & 515,403 & 389,457 & $1,824,218$ \\
\hline & 果計工 & 地荋 & with & $\mathrm{m}^{2}$ & $P N a_{i}{ }^{B j}$ & 929,441 & 542,511 & 397,428 & $1,869,380$ \\
\hline & & 力代 & without & 円 $/ \mathrm{m}^{2}$ & $r^{A j}$ & 11,673 & 9,918 & 9,189 & \\
\hline & & ST & with & 円 $/ \mathrm{m}^{2}$ & $r^{\bar{B} j}$ & 11,884 & 10,162 & 9,240 & \\
\hline & & 地代 & 式 (22a) & 巴 $/ m^{2}$ & $r\left(H_{1}{ }^{A j}\right)$ & 7,400 & 6,452 & 6,442 & \\
\hline & without & & 式(23a) & & $r\left(H_{0}{ }^{A j}\right)$ & 18,382 & 15,222 & 13,095 & \\
\hline & & 消費者余 & 式(22b) & 百万円/年 & $M D_{0}{ }^{A j}$ & 3,929 & 1,787 & 1,070 & 6,785 \\
\hline & & 剰の増分 & 式 $(23 b)$ & & $M D_{1}^{A j}$ & 6,168 & 2,734 & 1,521 & 10,423 \\
\hline & & 地代 & 式 $(24 a)$ & 円 $/ \mathrm{m}^{2}$ & $r\left(H_{0}^{B j}\right)$ & 8,084 & 6,773 & 6,216 & \\
\hline 年 & with & & 式 $(25 a)$ & $\mathrm{H} / \mathrm{m}$ & $r\left(H_{1}^{B j}\right)$ & 17,449 & 15,224 & 13,718 & \\
\hline & & 消費者余 & 式 $(24 b)$ & 百万円/年 & $M D_{0}^{B j}$ & 3,532 & 1,838 & 1,202 & 6,572 \\
\hline & & 剩の増分 & 式 $(25 b)$ & 日儿早 & $M D_{1}^{B}{ }^{B}$ & 5,172 & 2,746 & 1,780 & 9,698 \\
\hline 便 & & 地代 & 式 (26a) & 巴/ & $r\left(H_{0}^{A j}\right)$ & 14,099 & 14,122 & 11,254 & \\
\hline & 平常時 & & 式(27a) & 円 & $r\left(H_{0}^{B j}\right)$ & 9,836 & 7,129 & 7,542 & \\
\hline 㚇 & & 消費者余 & 式 $(26 b)$ & 百万円/年 & $M D_{0}^{A B j}$ & 1,689 & 1,437 & 641 & \\
\hline 桖 & & 剰の増分 & 式 $(27 b)$ & 日百円/年 & $M D_{0}^{B A j}$ & 2,059 & 2,149 & 801 & \\
\hline & & 地代 & 式(26a) & U $6 m^{2}$ & $r\left(H_{1}^{A j}\right)$ & 15,122 & 14,467 & 10,802 & \\
\hline & 洪水 & 地化 & 式 $(27 a)$ & 円 & $r\left(H_{1}^{B j}\right)$ & 9,168 & 6,958 & 7,859 & \\
\hline & 供小时 & 消費者余 & 式(26b) & 百无 & $M D_{1}{ }^{A B j}$ & 2,303 & 1,525 & 518 & \\
\hline & & 剩の増分 & 式(27b) & 日刀的出 & $M D_{1}^{B A j}$ & 3,010 & 2,336 & 621 & \\
\hline & & 合計 & & 百万円 $/$ 年 & & 2,761 & 2,142 & 856 & 5,760 \\
\hline 便益 & 現不 & 值 (社会的 & 引率 & 億 円 & & 552 & 428 & 171 & 1,152 \\
\hline
\end{tabular}

検討を中心に議論し，それ以外については今後の課題と したい. なお, 本研究では世帯のみを対象としている.

数值シミュレーションの結果を表-1の下段部分に示す. 各ゾーンの便益の現在価値は，それぞれ552億円，428億 円，171億円となり，合計では1,152億円となった．本研 究と同じ事業を対象に立地均衡モデルを適用して算出し た便益の合計が1,076億円 ${ }^{8)}$ であり，その差は7\%前後であ るので，近似的な值が得られていることが確認できた.

また，治水経済調查（改訂前の手法を使用）による同事 業の期待被害軽減額の現在価值は919億円 ${ }^{18)}$ であり, 本モ デルによる便益はこの約1.25倍となっている. 本モデル では資産形成過程をモデル化している訳ではないため, 被害（軽減）額との関係は明示的でないが，本モデルが 社会的総便益を表していれば, その差の233億円は高度化 便益等を表していると考えられる.

\section{7.おわりに}

本研究では, 不確実性を考慮した社会経済モデルを構 築し, Non-Contingent EVを便益定義とした後, Gorman 型効用関数を適用することにより社会的純便益の帰着形
を示し，それに市場均衡条件を考慮して展開することに よって，防災投資の便益を近似的にかつ簡便に計測でき るショートカット法を提案した.

このショートカット法では, 防災投資による社会的純 便益が，防災投資を実施した場合としなかった場合のそ れぞれについて，災害時と平常時の消費者余剩の差をと り災害発生確率の変化を乗じて地域毎に合計して求めた 值と，災害時と平常時のそれぞれについて，防災投資 を実施した場合としなかった場合における消費者余 剩の差を求め, その期待値を地域毎に合計して求めた 值の和から，防災投資額分を差し引いて計測できること を示した。

最後にある治水事業を対象に便益計測の数值シミュレ ーションを行った．その結果近似的な值が得られること が確認できた。しかし，本研究では立地均衡モデルに用 いた効用関数を利用して各ケースの地代を推定しており， 実証的に本手法の利点である便益の簡便性を証明し切れ ていないと思われる.この点については様々な実際の防 災投資に適用し，妥当性や適用範囲について検討すると ともに推定精度の精度向上を図ることを今後の課題とし たい. 
謝辞：本稿作成にあたっては上田孝行先生(東京工業大 学), 森杉壽芳先生(東北大学)から貴重なコメントを頂い た.ここに記して感謝の意を表する. また, 細部にわた るまで注意媣く原稿に目を通し，多くの指摘を下さった 匿名の査読者の方々にも，この場を借りて謝意を表した い. 無論, 本稿の見解と含まれる誤りについては筆者の みが責任を負っている.

\section{参考文献}

1) 建設省河川局 : 治水経済調査マニュアル(案), 1999.

2) Graham D.A. : Cost-Benefit Analysis Under Uncertainty, American Economic Review, Vol.71, pp.715-725, 1981. 及 び Graham D.A. : Cost-Benefit Analysis Under Uncertainty Reply, American Economic Review, Vol.74, pp.1100-1102, 1984.

3) 多々納裕一: 不確実性下のプロジェクト評価 : 課題と 展望, 土木計画学研究·論文集, No.15, pp.19-30, 1998.

4) 上田孝行: 防災投資の便益評価一不確実性と不均衡の 概念を念頭に置いて一土木計画学研究・論文集, No.14, pp.17-34, 1997.

5) 高木朗義 -上田孝行 - 長谷川俊英・森杉壽芳 : 不確実 性下の便益定義に関する考察, 土木計画学研究・講演 集, No.20(2), pp.375-378, 1997.

6) 森杉壽芳・大野栄治・宮城俊彦 : 住環境整備による住 み替え便益の定義と計測モデル, 土木学会論文集, 第 425号/IV-14, pp.117-125, 1991.

7) 上田孝行 : 交通・立地分析モデルによる都市交通プロ ジェクトの影響分析, 日交研シリーズ, A-184, 1995.
8) 高木朗義・森杉壽芳 - 上田孝行 - 西川幸雄・佐藤尚 : 立地均衡モデルを用いた治水投資の便益評価手法に 関する研究, 土木計画学研究・論文集, No.13, pp.339-348, 1996.

9) 例えば，道路投資評価研究会著 : 道路投資の社会経済 評価，中村英夫編，東洋経済新報社，1997。

10)Kanemoto, Y. and Mera, K. : General Equilibrium Analysis of the Benefits of Large Transportation Improvement, Regional Science and Urban Economics, Vol.15, No.10, pp.343-363; 1985.

11)森杉壽芳・林山泰久・小島信二 : 交通プロジェクトに おける時間便益評価 : 簡便化手法の実用化と精度の検 討, 土木計画学・論文集, No.4, pp.149-156, 1986.

12)森杉壽芳・大野栄治・ 小池淳司・武藤慎一 : 公園整備 事業の便益評価一新しい非市場評価法の提案一, 土木 学会論文集, 第518号/IV-28, pp.135-144, 1995.

13)大野栄治: ランダム効用理論による交通便益の定義と その計測に関する研究, 京都大学博士論文, 1992.

14)Johansson, P.-O. : The Economic Theory and Measurement of Environmental Benefit, Cambridge University Press, 1987.

15)土木学会編 : 非集計行動モデルの理論と実際, 土木学 会, 1995.

16)酒井泰弘 : 不確実性下の経済学, 有斐閣, 1982.

17)ハル・R・ヴァリアン：ミクロ経済分析,勁草書房, 1986.

18)高木朗義・大野栄治・森杉壽芳・沢木真次 : 治水事業 の経済効果計測に関する研究, 土木計画学研究・論文 集, No.11, pp.191-198, 1993.

\section{防災投資の簡便な便益計測法に関する研究}

高木 朗義

防災投資の便益を計測するためには, 災害の特性である不確実性, 地域性を捉える必要がある. 本研究 ではこのことを念頭に置き，現場で使用できる簡便な便益計測手法を提案するものである．具体的には， 不確実性下において社会経済モデルを構筑し, Non-Contingent EVで便益を定義してその帰着形を示すとと もに, 市場均衡条件から便益のキャンセル特性を考慮したショートカット形を導出した. そしてそれを近 似的にかつ簡便に計測できるショートカット法を提案した. また実際の治水事業を対象に便益計測の数值 シミュレーションを行い, 近似的な值が得られることを確認した.

The Simple Benefit Measurement Method of Natural Disaster Prevention Projects

\section{By Akiyoshi TAKAGI}

The uncertainty and spatiality which are characteristics of disasters, to measure the benefit of natural disaster prevention projects must be caught. This paper proposed the simple benefit measurement method that is able to use in the practical cost benefit analysis. I constructed the socioeconomic model under uncertainty, defined benefit with Non-Contingent EV, showed the incidence form, and led the form based on the characteristic which benefit was cancelled in the markets. And I proposed the short cut method to be able to measure benefit simply and approximately. It was confirmed that the value of an approximation is obtained, by measuring the benefit of the flood control works. 